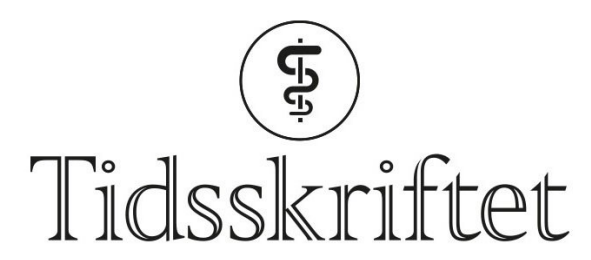

DEN NORSKE LEGEFORENING

\title{
Gjør helsepersonell flere feil når de blir avbrutt av telefoner?
}

FRA ANDRE TIDSSKRIFTER

LISE SKOGSTAD LOFTSGAARD

Tidsskriftet

Forstyrrelser i form av telefonanrop til sykepleierne var assosiert med flere feil i medisinadministreringen på en barneintensivavdeling i USA.

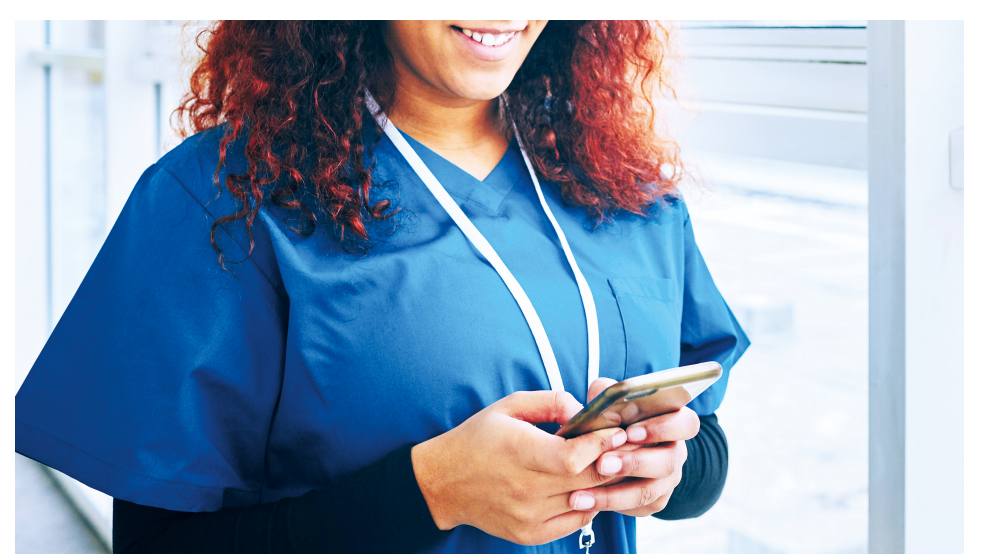

Illustrasjonsfoto: Dean Mitchell / iStock

Mobiltelefon brukes mer og mer som et hjelpemiddel på sykehus. I en retrospektiv studie ved en barneintensivavdeling i USA ble data fra pasientjournaler og sykehusets telekommunikasjonssystem gjennom ett år analysert (1). Innkomne telefonanrop og tekstmeldinger ble definert som avbrytelser dersom de inntraff maksimalt ti minutter før administrering av medisiner til pasientene.

Til sammen 257 sykepleiere administrerte medisiner om lag 240 ooo ganger i løpet av studieperioden. Når sykepleiere ble avbrutt av innkomne telefoner, ble det registrert feil i 3,7 \% (95\% KI, 3,4-4,0) av tilfellene, mot 3,1 \% ( 95 \% KI 3,O-3,3) når sykepleierne ikke ble avbrutt. Risikoen var størst om natten, hos uerfarne sykepleiere, særlig ved ansvar for mange pasienter, og hos pasienter med stort pleie- og behandlingsbehov. Avbrudd på grunn av tekstmeldinger viste ingen forskjeller.

- Denne studien viser at det er en kompleks sammenheng mellom telefonisk avbrytelse og feil under medisinadministrering, sier Athar Ali Tajik, som er medisinsk fagdirektør ved Statens undersøkelseskommisjon for helse- og omsorgstjenesten.

- Feilraten påvirkes av mange faktorer, og det er derfor usikkert i hvilken grad resultatene er generaliserbare, legger han til. 
- Helsepersonell må håndtere sine vanlige oppgaver samtidig som de har ansvar for vakttelefon. Erfaringer fra andre risikokritiske samfunnsområder viser imidlertid at avbrytelser kan føre til alvorlige uhell, og mye tyder på at dette også gjelder helsevesenet. Vi trenger mer kunnskap om hvilke faktorer som spiller inn på hvordan avbrytelser påvirker risikoen for uønskede hendelser. Vi må være åpne for å tilpasse bruk av telefon og andre kilder til avbrytelser på en måte som styrker pasientsikkerheten samtidig som behovet for akutt beredskap ivaretas, sier han.

\section{LITTERATUR:}

1. Bonafide CP, Miller JM, Localio AR et al. Association between mobile telephone interruptions and medication administration errors in a pediatric intensive care unit. JAMA Pediatr 2019; 174:162-9. [PubMed][CrossRef]

Publisert: 15. april 2020. Tidsskr Nor Legeforen. DOI: 10.4045/tidsskr.20.0109 (C) Tidsskrift for Den norske legeforening 2020. Lastet ned fra tidsskriftet.no 